\title{
Peningkatan Kualitas Sumber Daya Manusia Melalui Pendidikan Islam
}

\author{
Djuwarijah $^{1}$
}

\begin{abstract}
Abstrak
Pendidikan merupakan interaksi antara manusia dengan lingkungannya termasuk lingkungan alam dan lingkungan manusi. Di dalam intearksi tersebut manusia bukan hanya hasil interaksi dengan alamnya dan dengan sesama manusia, melainkan hasil pegembangan potensi manusia secara optimal sesuai dengan fitrahnya. Dengan adanya kecenderungan pemanfaatan pendidkan Islam yang berbasis pada masyarakat (community based education management), maka terdapat suatu ruangan yang terbuka bagi pengembangan inovasi dan kreativitas. Pendidikan Islam diharapkan dapat lebih berkembang sehingga lembaga pendidikan Islam memiliki daya tarik tersediri, karena lebih berdimensi keluar dan global.

Proses peningakatan kualitas sumber daya manusia memerlukan berbagai prasyarat di dalam pelaksanaannya, antara lain lingkungan kehidupan manusia hendaknya memberikan kesempatan kepada perkembangan peserta didik untuk berkembang sesuai dengan potensi yang ada padanya.

Pendidikan Islam, dalam pertumbuhan spiritual dan moral akan mampu menolong individu menguatkan iman, akidah, dan pengenalan terhadap Allah SWT, melalui hukum, moral dan ajaran agama, dengan demikian peserta didik dalam melaksnakan tuntunan iman kepada Allah SWT dan pemahaman yang mendalam terhadap ajaran agama dan nilainya dalam kehidupan pada tingkah lakunya, dan hubungannya dengan Allah SWT dengan sesama manusia dan seluruh makhluk, akan mempertegas pentingnya pendidikan akhlak dan spiritualitas dalam menyongsong globalisasi.
\end{abstract}

Kata kunci: kuallitas SDM, pendidikan islam, pendidikan agama Islam.

\footnotetext{
${ }^{1}$ Dosen Program Studi Pendidikan Agama Islam Fakultas Ilmu Agama Islam Universitas Islam Indonesia Yogyakarta.
} 


\section{A. Pendahuluan}

Di era persaingan global ini, trend pendidikan mengalami pergeseran orientasi yang menempatkan pembangunan manusia seutuhnya melalui pendidikan dan latihan dengan beragam jenis, jenjang, sifat dan bentuknya. Pendidikan manusia Indonesia seutuhnya diidealisasikan menjadi titik puncak tercapainya pendidikan nasional yang sampai saat ini menjadi dambaan bangsa Indonesia. Sosok pribadi yang diidolakan belum juga dihasilkan, maka lembaga pendidikan dijadikan ekspektasi alternatif, sebagai instrumen utama proses kemanusiaan dan pemanusiaan, yaitu menghargai dan memberi kebebasan untuk berpendapat dan berekspresi. Penghargaan yang demikian adalah benih yang mulai tumbuh, dan sebagai sebuah proses kebebasan terus-menerus diperjuangkan (Mahmud ed., 2005: 256).

Bagaimana mungkin bisa menjadi manusia yang sesungguhnya, kalau dalam realitasnya memang pendidikan Islam sebagai subsistem dinilai masih kering dari aspek pedagogis, dan lebih mekanistik dalam menjalankan fungsinya sehingga terkesan hanya akan melahirkan peserta didik yang "kerdil" karena tidak memiliki dunianya sendiri. Menurut Ma'arif (2007: 105) konsep pendidikan telah dipaksa untuk menuruti konsep development-kapitalis yang terelaborasi sedemikian rupa, demi memenuhi kebutuhan industrialisasi, sehingga pendidikan yang seharusnya menjadi media pemberdayaan malah menjadi sarana pembodohan yang sistematis, penciptaan robot-robot intelektual yang terprogram secara maraton dan monoton.

Pendidikan Islam dewasa ini, benar-benar telah menjadi salah satu wilayah yang banyak mengeluarkan biaya. Pendidikan yang pada hakekatnya adalah untuk semua (education for all), sebagai hak individu warga negara dan juga warga dunia memiliki hak memperoleh pendidikan secara adil. Ternyata, hal yang semestinya merupakan hak tersebut kini tergantikan oleh pendidikan sebagai barang dagangan. Pendidikan menjadi ritus masyarakat yang membodohkan. Bahkan pendidikan menjadi penyebab terjadinya ketidak adilan, karena masyarakat yang mampu sekolah adalah golongan elite yang kaya sedangkan mereka yang tidak mampu sekolah adalah masyarakat miskin.

Di sisi lain, menurut Fadjar (dalam Rahardjo, 2006: 11) kurang tertariknya masyarakat untuk memilih lembaga-lembaga pendidikan Islam sebenarnya bukan kerena telah terjadi pergeseran nilai atau ikatan keagamaannya yang mulai memudar, melainkan 
karena sebagian besar lembaga pendidikan Islam yang ada kurang menjanjikan masa depan dan kurang responsif terhadap tuntutan dan permintaan saat ini maupun mendatang. Padahal, paling tidak ada tiga hal yang menjadi pertimbangan masyarakat dalam memilih lembaga pendidikan, yaitu nilai (agama), status sosial dan cita-cita. Masyarakat yang terpelajar akan semakin beragam pertimbangannya dalam memilih pendidikan bagi anak-anaknya.

Fenomena seperti diuraikan di atas, dalam memilih lembaga pendidikan untuk menyekolahkan anak-anak mereka pun sudah sangat rasional dan mempertimbangkan prospektif ke depan. Mereka yang berpeluang memilih, akan menentukan pilihan kepada lembaga pendidikan yang dipandangnya ideal. Lembaga pendidikan yang dipandang ideal itu adalah lembaga yang mampu mengembangkan potensi spiritual dan akhlak para peserta didik, yang mampu mengembangkan aspek intelektual, yang biasanya diukur dari perolehan NEM, dan lembaga pendidikan yang mampu mengembangkan potensi sosial maupun keterampilan peserta didiknya. Lembaga yang bertipe ideal itu biasanya diperebutkan orang, sehingga biayanyapun menjadi mahal, mengikuti hukum pasar, yakni supply and demand.

Tuntutan masyarakat seperti itu telah direspons banyak pihak, tidak terkecuali oleh lembaga pendidikan keagamaan, di antaranya lembaga pendidikan Islam dengan memunculkan lembaga pendidikan integratif, atau sekolah/ madrasah terpadu, sekolah/ madrasah model, atau bentuk-bentuk sekolah/madrasah unggulan lain, yang mengedepankan kualitas (Suprayogo, 2007: 56). Dengan menggunakan term integratif diharapkan para lulusannya meraih kedewasaan kepribadian secara utuh, yaitu dewasa spiritual, dewasa intelektual, dewasa sosial, dan dewasa kecakapan hidupnya.

Dengan memperhatikan realitas di atas, maka substansi persoalannya adalah tugas pendidikan tidak mengalami pergeseran nilai, yaitu mencerdaskan peserta didik, sedangkan biaya tidak dapat dijadikan ukuran pendidikan itu berkualitas atau tidak. Gagasan adanya pendidikan murah demi tercapainya pemerataan pendidikan adalah gagasan yang berpihak pada masyarakat tidak mampu agar mengenyam pendidikan yang berkualitas. Sedangkan peran ganda pendidikan adalah (1) Pendidikan berfungsi untuk membina kemanusiaan (human being), berarti pendidikan pada akhirnya untuk mengembangkan seluruh pribadi manusia, termasuk mempersiapkan manusia sebagai anggota masyarakatnya, warga negara yang baik, dan rasa persatuan; (2) Pendidikan berfungsi sebagai pengembangan 
sumber daya manusia (human resources), yaitu mengembangkan kemampuannya memasuki era kehidupan baru.

Berdasarkan latar belakang persoalan di atas, akan dibahas persoalan yang dihadapi pendidikan Islam dan upaya pemberdayaan lembaga pendidikan Islam untuk mempersiapkan sumber daya manusia yang unggul dalam menghadapi tantangan zamannya.

\section{B. Pengembangan Sumber Daya Manusia}

Investasi pengembangan sumber daya manusia selalu berjangka panjang. Program pengembangan jangka panjang ini mempersiapkan manusia terdidik yang memiliki ilmu pengetahuan dan mempunyai kualitas yang tinggi, yaitu manusia yang berkaliber nasional dan internasional. Adanya gejala pengangguran manusia terdidik dewasa ini perlu mendapatkan perhatian serius. Misalnya, perlu dilakukan peninjauan ulang terhadap isi dan arah kurikulum pendidikan yang tidak sejalan dengan kebutuhan pembangunan. Perlu pengembangan paradigma pendidikan yang memposisikan individu yang mandiri, pembelajar, dan mengupayakan pengembangan serta pemberdayaan potensi untuk menjadikan dirinya sebagai khalifah $f i$ al-'ardh.

Upaya peninjauan kurikulum harus dibarengi dengan perubahan perilaku pendidik selama ini yang lebih menekankan adanya penindasan terhadap peserta didik. Punishment lebih didahulukan dan dikembangkan dari pada reward dan pemberian apresiasi. Padahal pendidikan yang ideal dan dapat mengembangkan potensi diri agar mandiri adalah pendidikan yang mengedepankan reward dan apresiasi kepada peserta didik dari pada punishment dan penindasan yang justru mengerdilkan jiwa peserta didik, membuatnya tidak kreatif dan tidak mandiri.

Ketahanan suatu masyarakat ditentukan oleh tiga unsur ialah sumber daya alamnya, sumberdaya manusianya yang berkualitas, dan sumber daya kebudayaan dan kesejarahannya (Tilaar, 2002: 60). Hanya anggota masyarakat yang berbudaya, yaitu yang mempunyai kebanggaan terhadap masyarakat dan budayanya, akan menjadi unsur sumber daya manusia yang produktif di dalam era globalisasi. Manusia yang tidak berbudaya akan tenggelam dalan arus globalisasi dan dia tidak mepunyai identitas. Globalisasi sangat mempengaruhi negara-negara berkembang, tidak terkecuali Indonesia yang berpenduduk mayoritas Muslim. Pengaruh yang demikian itu juga akan dialami warganya, sumber daya manusianya. Oleh karena itu kesiapan bangsa Indonesia menghadapi era globalisasi ialah 
persoalan peningkatan seutuhnya sumber daya manusia, yaitu kualitas manusia dengan keseimbangan aspek material dan aspek spiritual/nilai keagamaan.

Investasi sumber daya manusia sebagai anggota masyarakat yang diperlukan adalah memiliki karakteristik sebagai berikut: (1) Manusia yang berwatak, yaitu jujur dan memiliki social capital: dapat dipercaya, suka kerja keras, jujur, dan inovatif. Dengan istilah lain, manusia yang beretika dengan taat menjalankan ajaran agamanya; (2) Cakap dan inteligen; inteligensi ini harus dikembangkan sesuai apa yang dimiliki oleh masing-masing individu; (3) Entrepreneur wiraswasta), sikap entrepreneur bukan hanya di bidang ekonomi dan bisnis tetapi juga unruk semua aspek kehidupan, karena kemampuan entrepreneur cenderung bersifat inovatif dan tidak terikat kepada sesuatu yang tetap, sehingga tidak mengenal istilah "menganggur"; (4) Kompetitif, sumber daya manusia yang diperlukan adalah yang memiliki kualitas kompetitif dalam kehidupan dunia terbuka untuk selalui menggapai nilai lebih dan meningkatkan kualitas produktifitas kerjanya. Sikap kompetitif harus sudah mulai ditumbuhkan sejak di dalam keluarga, dan juga setiap jenjang pendidikan formal.

\section{Pendidikan Islam sebagai Subsistem Pendidikan Nasional}

Pendidikan Islam sebagai subsistem pendidikan nasional. Sebagai subsistem, pendidikan Islam mempunyai tujuan khusus yang harus dicapai, dan tercapainya tujuan tersebut akan menunjang pencapaian tujuan pendidikan nasional secara keseluruhan yang menjadi suprasistennya (Furchan, 2004: 14). Visi pendidikan Islam tentunya sejalan dengan visi pendidikan nasional. Visi pendidikan nasional adalah mewujudkan manusia Indonesia yang takwa dan produktif sebagai anggota masyarakat Indonesia yang bhinneka. Sedangkan misi pendidikan Islam sebagai perwujudan visi tersebut adalah mewujudkan nilai-nilai keislaman di dalam pembentukan manusia Indonesia. Manusia Indonesia yang dicita-citakan adalah manusia yang saleh dan produktif. Hal ini sejalan dengan trend kehidupan abad 21, agama dan intelek akan saling bertemu (Tilaar, 2004: 150).

Dengan misi tersebut pendidikan Islam menjadi pendidikan alternatif. Apabila pendidikan yang diselenggarakan oleh atau lembaga-lembaga swasta lainnya cenderung untuk bersifat skuler 
atau memiliki ciri khas lainnya, maka pendidikan Islam ingin mengejawantakan nilai-nilai keislaman. Ciri khas tersebut dengan tepat dirumuskan oleh Zarkowi Soejoeti. Menurut beliau apa yang disebut pendidikan Islam mempunyai tiga ciri khas berikut: (1) Suatu sistem pendidikan yang didirikan karena didorong oleh hasrat untuk mengejawantahkan nilai-nilai Islam; (2) Suatu sistem yang mengajarkan ajaran Islam, dan (3) Suatu Sistem pendidikan Islam yang meliputi kedua hal tersebut (Fadjar, 1998: 1).

Dengan pengertian yang diberikan Zarkowi tersebut dapat lebih dipahami bahwa keberadaan pendidikan Islam tidak sekedar menyangkut persoalan ciri khas, melainkan lebih mendasar lagi, yaitu tujuan yang diidamkan dan diyakini sebagai yang paling ideal. Tujuan itu sekaligus mempertegas bahwa misi dan tanggung jawab yang diemban pendidikan Islam lebih berat lagi. Ketiganya itu selama ini tumbuh dan berkembang di Indonesia dan sudah menjadi bagian tidak terpisahkan dari sejarah maupun dari kebijakan pendidikan nasional. Bahkan tidaklah berlebihan jika dikatakan bahwa kehadiran dan keberadaannya merupakan bagian dari andil umat Islam dalam perjuangan maupun mengisi kemerdekaan.

Di Indonesia, pendidikan Islam ini tampil dalam berbagai macam wujud, yaitu pendidikan agama Islam yang merupakan substansi dari sistem pendidikan agama dalam kurikulum nasional, pendidikan di madrasah dan sekolah umum Islam yang merupakan subsistem dari sistem pendidikan umum (formal), pendidikan pesantren yang merupakan subsistem dalam pendidikan nonformal.

\section{Profil Lulusan Pendidikan Islam}

Pendidikan Islam dituntut merumuskan profil yang bagaimana sebenarnya yang diharapkan oleh sistem pendidikan ketika berhadapan dengan globalisasi. Rumusan tersebut menjadi sangat penting karena deskripsi profil output yang relevan dengan konteks globalisasi yang dapat dijadikan landasan bagi terwujudnya tujuan ideal yang diharapkan sesuai tantangan zaman.

Tentu saja, perumusan profil yang diharapkan pendidikan Islam tidaklah sederhana seperti gambaran dan impian orangtua dahulu ketika memasukkan putra putrinya ke madrasah maupun pesantren, yaitu agar mereka setelah lulus mampu menjadi imam masjid, memimpin tahlil dan manakib, berprilaku sopan, dan mampu membaca kitab berbahasa Arab, sedangkan mereka buta akan perkembangan dunia luar. Profil seperti inipun baik, tetapi akan lebih 
baik kalau dirubah menyesuaikan dengan tuntutan kondisi objektif dan dinamika masyarakat, yaitu dengan mengintegrasikan ulama yang intelek atau intelek yang ulama. Ulama adalah ilmuwan Muslim yang mendalami ilmu agama dan memperoleh kredibilitas moral dari masyarakat karena konsistensinya terhadap ilmu yang didapati dan misi yang diemban. Sedangkan intelektual, secara lughawi, adalah mereka yang memperoleh kekuatan intelektualitas; kekuatan berpikir dan menganalisis. Dalam pengertian ini scholarship menyamakan pengertian ulama dan intelektual (Mas'ud, 2003: 253).

Sosok lulusan yang diharapkan oleh pendidikan Islam sekurangkurangnya adalah ilmuwan yang ulama, dengan ciri-ciri sebagai berikut; (1) Peka terhadap masalah. Karena kepekaan seperti itu merupakan langkah kreatif untuk memulai pekerjaan; (2) Bekerja tanpa pamrih. Dalam tradisi keilmuan, bekerja tanpa pamrih ini berarti sikap objektif, cinta kebenaran serta kritis; (3) Bersikap bijaksana. Kebijakan mengandung makna adanya hubungan timbalbalik antara pengetahuan dan tindakan, antara pengertian teoritis dan pengertian praktis etis yang sesuai; (4) Tanggung jawab. Seorang ilmuwan berkewajiban mencari, menemukan dan memanfaatkan ilmu bagi kepentingan hidup umat manusia, sekaligus juga bertanggung jawab atas apa yang terjadi selanjutnya jika dengan ilmu itu ternyata menimbulkan kerusakan lingkungan alam ini, ia berusaha mencari lagi jalan keluarnya.

Dengan demikian, sosok manusia yang unggul dihasilkan dari pendidikan Islam adalah mereka yang cerdas, kreatif dan beradab. Dengan kecerdasan (phisik, intelektual, sosial, emosional, dan spiritual) diyakini akan mampu menghadapi globalisasi dan segala tantangannya, mereka itulah manusia yang saleh, insan kamil, dengan berbagai ketrampilan dan kemampuan serta mandiri untuk menjadi 'abdullah sekaligus khalifatullah di muka bumi. Term khalifah yang berarti wakil, utusan, perwakilan dieksplorasi lebih jauh oleh M. Iqbal dalam The Reconstruction of Religious Thought in Islam yang menjelaskan bahwa Islam menekankan individualitas dan keunikan manusia (Mas'ud, 2003: 70). Konsekuensi dari keunikan manusia itu adalah tidak mungkin seorang individu harus menanggung beban orang lain, manusia hanya menanggung apa yang telah diperbuat.

Kebijaksanaan penididikan Islam yang harus diutamakan adalah membantu setiap peserta didik dapat berkembang secara optimal, yaitu dengan: (1) menyediakan guru yang profesional, yang seluruh waktunya dicurahkan untuk menjadi pendidik; (2) 
menyediakan fasilitas sekolah yang memungkinkan peserta didik dapat belajar dengan penuh kegembiraan dengan fasilitas olah raga dan ruang bermain yang memadai; (3) menyediakan media pembelajaran yang kaya, memungkinkan peserta didik dapat secara terus menerus belajar melalui membaca buku rujukan serta kelengkapan laboratorium dan perpustakaan dan (4) evaluasi yang terus menerus secara komprehensif dan objektif.

\section{E. Aplikasi IQ, EQ dan SQ dalam Pendidikan Agama Islam}

\section{Kecerdasan Intelektual}

Pada dasarnya manusia itu dianugrahi oleh Allah SWT berbagai macam kecerdasan, dan tanggung jawab pendidikan adalah memperhatikan dan mengarahkan kecerdasan tersebut agar mampu berkembang secara optimal dan seimbang. Tidak ada keseimbangan dalam penanganannya akan mengakibatkan masalah dikemudian hari.

Dalam diri manusia terdapat kecerdasan yang disebut dengan kecerdasan intelektual (Intelligence Quotient/ IQ). Anak-anak yang cerdas, yang karena itu dianggap pasti sukses dalam kehidupan, adalah mereka yang nilai rapornya bagus semua atau indeks prestasinya di atas rata-rata. Sejak Wilhelm Stern, Psikolog Jerman yang banyak mengacu pada teori inteligensi Alfred Binnet dan Theodore Simon menyebut IQ sebagai ukuran kecerdasan. Akibatnya titik berat pendidikan di Indonesia yang menganut teori intelegensi ini adalah hanya memberi kesempatan berkembang pada otak kiri saja, membuat otak kanan terbengkalai. Ujian Akhir Semester (UAS), hanya sanggup mengukur otak kiri peserta didik yang hasilnya bukan gambaran utuh kecerdasan peserta didik (Pasiak, 2003: 121).

Pendidikan Islam bertugas meningkatkan, mengembangkan, dan menumbuhkan kesediaan, bakat-bakat, minat-minat, dan kemampuan-kemampuan akal peserta didik serta memberinya pengetahuan dan keterampilan akal yang perlu dalam hidupnya. Pendidikan Islam didasarkan pada pandangan yang komprehensif tentang manusia. Karena letak keistimewaan manusia adalah makhluk berpikir dan berakal, maka pendidikan bertugas dan bertanggungjawab mendorong kepada manusia untuk tahu dan mengerti. Dengan akalnyalah manusia memungkinkan untuk berpikir, merasa dan percaya dalam rangka untuk bisa menetapkan 
putusan dan tindakan serta tanggung jawab terhadap segala persoalan yang dihadapinya.

Mengingat urgensinya intelektual bagi kehidupan manusia, maka tidaklah berlebihan jika Islam sangat menghargai manusia yang memiliki kecerdasan intelektual (quwwah al-fiqriyyah). Kalau kecerdasan intelektual ini tidak terkendali dapat menimbulkan jarbazah (sikap angkuh dan mengabaikan fungsi wahyu), dan kalau tidak dikembangkan membuat seseorang menjadi baladah (bodoh). Islam memberikan arahan agar kecerdasan intelektual ini dikembangkan secara proposional dan ditempatkan pada posisi al-hikmah (kearifan). Sifat al-hikmah inilah yang menimbulkan kemampuan berpikir, cerdas, dan cepat tanggap terhadap perkembangan yang terjadi (Ma'arif, 2007: 129).

Agar pendidikan agama Islam dapat mengaktualisasikan IQ secara optimal, maka diperlukan latihan berpikir kritis pada diri peserta didik. Sebab berpikir kritis merupakan cara berpikir yang esensial bagi manusia. Dengan cara peserta didik diberi kesempatan untuk berpikir tentang sesuatu terlebih dahulu melalui penyelidikan dan tidak begitu saja menerima ide atau gagasan tanpa bukti yang nyata, tidak tergesa-gesa menarik kesimpulan yang beraku secara umum. Dengan cara demikian peserta didik terbiasa menyelidiki kebenaran pendapat orang lain dan mengecek kebenaran pendapat pribadinya.

Keberhasilan proses belajar mengajar materi Pendidikan Agama Islam, sangat ditentukan keberhasilannya oleh guru. Untuk itu guru disamping dituntut memiliki kompetensi profesional, juga menjalankan tugasnya dalam suasana yang menyenangkan dan efektif.

\section{Kecerdasan Emosi}

Fenomena yang terjadi akhir-akhir ini seperti penjarahan, pembakaran, perampasan, pembunuhan, penculikan, perkosaan, tawuran, tindak kekerasan dan kekejaman yang dilakukan anak bangsa yang mewarnai panggung dunia pendidikan di tanah air sungguh memilukan dan memalukan. Bangsa yang dikenal sebagai bangsa yang ramah, peduli, murah senyum berubahn menjadi bangsa yang menakutkan dan mengerikan bangsa lain adalah salah satu bukti kesalahan pendidikan yang hanya berorientasi pada kecerdasan intelektual belaka.

Emotional Quotient (EQ) atau kecerdasan emosi ikut menentukan 
keberhasilan dalam hidup ini bukan hanya IQ. Banyak hal yang secara logika benar tetapi perasaan menyatakan bahwa hal itu tidak benar, karena itulah sering diperlukan keahlian kecerdasan akal didampingi kecerdasan emosi. Kecerdasan emosi berbeda dengan kecerdasan intelektual, sebab kecerdasan emosi merupakan kemampuan mengelola, mengendalikan emosi, menggunakan intuisi, indera, kepekaan yang justru tidak melibatkan daya nalar manusia.

Kalau kecerdasan intelektual diukur dengan IQ, maka kecerdasan emosi merupakan kemampuan non-kognitif. IQ tidak membuat seseorang menjadi unik, tetapi perasaan-perasaan yang ada pada diri seorang anak dan bagaimana anak menyikapi perasaannyalah yang menjadikan anak itu unik. Namun demikian, antara IQ dan EQ bukanlah kemampuan yang saling bertentangan, tetapi kemampuan yang sedikit terpisah.

Kecerdasan Emosi merupakan "the inner rudder", kekuatan dari dalam, sifatnya alami, dan dapat dikembangkan dengan kuat melalui berbagai akumulasi pengalaman yang panjang dan beragam. Ada lima wilayah utama EI, yakni: mengenali emosi diri, mengendalikan emosi diri, memotivasi diri, mengenali emosi orang lain, dan membina hubungan dengan orang lain. Optimisme dan positive thinking memberi pengaruh menguntungkan dalam kondisi biologis manusia (Pasiak, 2003: 272).

Selama ini ada kemungkinan pembelajaran di kelas cepat mendatangkan kejenuhan dan kebosanan dikarenakan tidak adanya keterlibatan emosi di dalamnya. Guru hanya mengikuti instruksi dari buku-buku yang berisi petunjuk pengajaran dan materi apa yang akan diajarkan secara berurutan. Tak ada lagi kesempatan guru untuk mengaitkan materi pelajaran dengan kehidupan terdalam sang guru, apa lagi dengan kehidupan peserta didik yang beraneka ragamnya. Sebagai contoh, guru PAI mengajarkan materi tentang puasa, sedangkan yang diajarkan hanyalah pengertian puasa, syarat, rukun, dan yang membatalkan puasa, yang sama sekali tidak menyentuh emosi terdalam setiap orang. Memang hal tersebut penting untuk diketahui peserta didik namun ada yang lebih penting seperti mengetahui hikmah dan manfaat puasa bagi kehidupan. Hal ini penting, karena ibadah (puasa) yang memancarkan hikmah bukan saja diperlukan untuk pembinaan kesalehan individual, melainkan juga peningkatan kesalehan sosial. 


\section{Kecerdasan Spiritual}

Kehidupan masyarakat skuler sudah bergeser ke arah materialis dan hedonis. Perkembangan globalpun bisa berdampak positif, namun juga negatif. Dampak positifnya, kemajuan ilmu pengetahuan dan teknologi dapat membantu manusia untuk mengakses berbagai informasi secara cepat tentang peristiwa yang ada di belahan dunia untuk kemajuan hidupnya, namun dampak negatifnya informasi yang masuk dapat menjadi akar penyebab keretakan kesatuan dan persatuan bangsa, bahkan dapat menghilangkan jati diri bangsa itu sendiri.

Perlu disadari, era globalisasi merupakan produk kemajuan sain dan teknologi, maka peningkatan kualitas sumber daya manusia muslim merupakan prasyarat untuk mencapai kemajuan di bidang sain dan teknologi. Di sinilah tantangan bagi pendidikan Islam dan para pemikirnya. Sehingga pendidikan Islam, disatu sisi mampu menyampaikan pesan Islam kaitannya dengan tuntutan kualitas SDM serta merebut kembali kejayaan sain dan teknologi; di sisi lain mampu mencetak SDM yang berkualitas, yaitu manusia yang ber IQ tinggi sekaligus memiliki kecerdasan spiritual (Spiritual Quotient) $\mathrm{SQ})$.

Pendidikan Islam dalam pertumbuhan spiritual dan moral harus mampu menolong individu menguatkan iman, akidah, dan pengetahuan terhadap Tuhannya dan dengan hukum-hukum, ajaran-ajaran, dan moral agamanya. Pendidikan spiritual (altarbiyah al-ruhiyyah), yang memiliki dimensi kemanusiaan seperti itu harus ditanamkan pada diri peserta didik melalui pendidikan Islam. Peran penting spiritual ini bagi kehidupan manusia adalah pendidikan Islam harus didasarkan pada falsafah bahwa pendidikan adalah proses menuju kesempurnaan dengan berbagai potensi yang diberikan oleh Allah untuk manusia agar dapat menjalankan misinya sebagai khalifatullah di muka bumi.

Pendidikan spiritual sebagai usaha sadar untuk menghantarkan peserta didik memiliki hubungan yang sangat kuat antara ruhani manusia dengan sang pencipta, Allah SWT. Sehingga dengan demikian, manusia dapat meraih pengenalan spiritual (ma'rifah ruhiyah). Hanya dengan pengenalan spiritual itulah, manusia mendapatkan spiritualisasi yang akan mengangkatnya pada kesucian dan keindahan insani, yang menjadikan segala aktifitas kehidupannya semakin bermakna.

Aspek spiritual yang perlu ditanamkan dalam pendidikan Islam 
adalah spiritualitas yang bukan hanya metode untuk pencarian makna, tetapi juga fondasi bagi pencarian itu sendiri. Karena itu, penguasaan, pengembangan dan pendayagunaan iptek yang tidak disertai dengan keluhuran akhlak akan dapat membawa manusia menuju penderitaan bahkan kehancuran. Oleh karena itu, penguasaan, pengembangan dan pendayagunaan ilmu pengetahuan dan teknologi harus senantiasa berada dalam jalur nilai-nilai kemanusiaan dan akhlak yang luhur.

Jika para tokoh Barat secara umum merancang penididikan skuler pada peserta didik, Islam sejak abad ke-7 telah mensosialisasikan ajaran yang serba religius. Pendapat John Locke sesungguhnnya sepuluh abad sebelumnya bisa ditemukan dalam hadits Nabi yang mengajarkan: "setiap anak lahir dalam keadaan putih bersih, fitrah, hingga kedua orangtuanya mendesainnya sebagai Yahudi, Nasrani, atau Majusi"(Hadits riwayat Bukhari, juz I: 1292). Nabi diikuti oleh tokoh-tokoh besar dalam pendidikan Islam seperti Ibnu Miskawaih (941-1030 M), Ibnu Hazm (w. 1064 M), Imam al-Ghazali (w. 1111 M), yang banyak menulis tentang akhlak dan pendidikan.

Dalam konteks pendidikan, Islam menempatkan anak pada posisi yang amat penting. Karena tugas suci ini termasuk fardhu 'ain bagi setiap orangtua, maka dosa besar bagi mereka yang tidak memperhatikan pendidikan agama anak. Nabi Muhammad SAW mengajarkan bahwa siapa yang tidak menyayangi anak maka bukan termasuk golongannya. Ancaman lebih keras bagi mereka yang tidak memperhatikan nasib yatim piatu. Kutukan Nabi dan Allah akan selalu menimpanya serta mendapatkan sebuah status tercela "pendusta agama". Betapa pentingnya pendidikan agama anak sebagai upaya menanamkan kecerdasan spiritual, sehingga Nabi mengingatkan bahwa seorang calon Bapak sudah semestinya memikirkan calon anak sejak ia menyeleksi calon ibunya. Karena menurut Nabi, darah ibu dan ayah akan mengalir ke tubuh anak dan sangat mempengaruhi masa depannya.

Pendidikan Islam sejak awal menekankan keimanan. Mencermati kisah Ibrahim dalam melakukan pencarian Tuhannya, lewat perpaduan antara menggunakan indera dan akalnya sekaligus. Pencarian hakekat Tuhan dengan menggunakan indera dan akal ternyata tak ketemu, sekalipun itu dilakukan oleh Ibrahim sebagai manusia yang menyandang gelar khalilullah (kekasih Allah). Sekalipun pencarian itu tidak membawa hasil tetapi dilakukan sebagai pintu memperoleh hidayah dari Allah. Kisah ini memberikan petunjuk bahwa indera dan akal tetap boleh digunakan untuk melakukan 
pengembaraan dan pergumulan melakukan pencarian Tuhan itu (Suprayogo, 2007:33-34).

\section{F. Kesimpulan}

1. Pendidikan Islam dapat memberikan solusi terhadap persoalan yang dihadapi manusia, mengingat pandangan tentang manusia yang menjadi objek dan subjek pendidikan yang komprehensif dan tujuannya adalah kesempurnaan dan keunggulan yang menjangkau kehidupan kini dan akhirat nanti ( $i$ al-dunya hasanah wa fi al'akhirati hasanah).

2. Profil lulusan pendidikan Islam merupakan hasil sintesis ulama dan intelektual dengan karakteristik sebagai berikut: (1) Peka terhadap masalah. Karena kepekaan seperti itu merupakan langkah kreatif untuk memulai pekerjaan; (2) Bekerja tanpa pamrih. Dalam tradisi keilmuan, bekerja tanpa pamrih ini berarti sikap objektif, cinta kebenaran serta kritis; (3) Bersikap bijaksana; (4) Tanggung jawab. Seorang ilmuwan berkewajiban mencari, menemukan dan memanfaatkan ilmu bagi kepentingan hidup umat manusia, sekaligus juga bertanggung jawab atas apa yang terjadi selanjutnya.

3. Memadukan IQ, EQ dan SQ dalam proses pembelajaran dengan mengembangkan potensi yang ada pada peserta didik secara optimal dan seimbang untuk mempersiapkan peserta didik sebagai khalifah Allah di muka bumi yang cerdas, mandiri, dan kreatif, serta bertanggung jawab kepada Allah Subhanahu Wata'ala.

\section{DAFTAR PUSTAKA}

Agustian, Ary Ginanjar, 2001. Rahasia Sukses Membangun Kecerdasan Emosi dan Spiritual Berdasarkan 6 Rukun Iman dan 5 Rukun Islam, Jakarta: Penerbit Arga.

Departemen Pendidikan Nasional RI, 2003. Undang-undang Republik Indonesia Nomor 20 Tahun 2003 Tentang Sistem Pendidikan Nasional, Jakarta: Departemen Pendidikan Nasional RI.

Fadjar, A. Malik, 1998. Madrasah dan Tantangan Modernisitas, Bandung: Mizan.

Furchan, Arief, 2004. Transformasi Pendidikan Islam di Indonesia, Yogyakarta: Gema Media. 
Idi, Abdullah dan Toto Suharto, 2006. Revitalisasi Pendidikan Islam, Yogyakarta: Tiara Wacana.

Ma'arif, Syamsul, 2007. Revitalisasi Pendidikan Islam, Yogyakarta: Graha Ilmu.

Mahmud, adnan, Sahjad M. Askan dan M. Adib Abdushomad (ed.), 2005. Pemikiran Islam Kontemporer di Indonesia, Yogyakarta: Pustaka Pelajar.

Mas'ud, Abdurrahman, 2003. Menuju Paradigma Islam Humanis, Yogyakarta: Gema Media.

Pasiak, Taufiq, 2003. Revolusi IQ/EQ/SQ Antara Neurosains dan Al-Quran, Bandung: Mizan.

Rahardjo, Mudjia (ed.), 2006. Quo Vadis Pendidikan Islam Pembacaan Realitas Pendidikan Isalam, Sosial dan Keagamaan, Malang: UIN Malang Press.

Suprayogo, Imam, 2007. Quo Vadis Madrasah Gagasan, Aksi \& Solusi Pembangunan Madrasah, Yogyakarta: Hikayat Publishing.

Tilaar, H.A.R., 2002. Membenahi Pendidikan Nasional, Jakarta: PT Rineka Cipta.

, Paradigma Baru Pendidikan Nasional, Jakarta: PT Rineka Cipta. 